УДК: $664.8 .047: 536.66$

\title{
THE INFLUENCE OF TECHNOLOGICAL REGIME PARAMETERS AND PRETREATMENT ON KINETICS DEWATERING AND ENERGY CONSUMPTION IN THE DRYING PROCESS PHYTOESTROGENIC MIXTURES
}

\author{
Petrova Zh. O., Slobodianiuk K. S., Dmytrenko N. V. \\ Institute of Engineering Thermophysics of NAS of Ukraine, Marii Kapnist street, 2a, Kyiv, 03057, Ukraine
}

https:doi.org/10.31472/ttpe.2.2020.4

\begin{abstract}
У статті викладені результати дослідження впливу попередньої підготовки фітоестрогенної сировини і ступеневої зміни температури в процесі сушіння на енерговитрати при виробництві сухих порошків. А також результати досліджень по визначенню витрат теплоти на випаровування вологи 3 фітоестрогенних рослинних сумішей: соя-морква і соя-шпинат.
\end{abstract}

В статье изложены результаты исследования влияния предварительной подготовки фитоэстрогенного сырья и ступенчатого изменения температуры в процессе сушки на энергозатраты при производстве сухих порошков. А также результаты исследований по определению затрат теплоты на испарение влаги из фитоэстрогенных растительных смесей: соя-морковь и соя-шпинат.
The article presents the results of a study of the effect of preliminary preparation of phytoestrogenic raw materials and stepwise changes in temperature during drying on energy consumption in the production of dry powders. As well as the results of studies to determine the cost of heat for evaporation of moisture from phytoestrogenic plant mixtures: soy-carrots and soy-spinach.

Bibliography 14, fig. 5.

Key words: phytoestrogens, moisture content, evaporation, drying, energy consumption.

$\mathrm{W}$ - relative humidity of the material, $\%$;

$\mathrm{W}_{\text {initial }}$ - initial humidity of the material, \%;

$r_{i}$ intital specific heat-costs consumption for evaporation during the time from $\tau_{\mathrm{i}-1}$ to $\tau_{\mathrm{i}+1}, \mathrm{~kJ} / \mathrm{kg}$;

$\tau_{i-1}$ and $\tau_{i+1}$ - the value of the current time, sec;

$q(\tau)$ - the heat flow inside the working chamber as a function of time, $\mathrm{J} / \mathrm{sec}$;

\section{Formulation of the problem in general.}

One of the tasks of Ukraine today is the rational use of agricultural products in order to reduce their losses. Vegetable raw materials are characterized by short shelf life [1]. Heat influence is one of the most widespread technological operations in the processes of processing of vegetable raw materials, and thermal heating in order to reduce the initial moisture content of processed raw materials (drying) is one of the most common ways of preserving, preparing and semi-fabricating food products $[2,3]$.

\section{Analysis of recent research and publications.}

Industrial energy consumption for the drying of raw materials sometimes reaches $25 \%$ of the total [2]. This puts the problem of development energy-saving drying technologies a top priority. Drying moisure material is one of the most effective means of processing it for long-term storage [4]. When simulating the process of drying plant $m\left(\tau_{\mathrm{i}-1}\right)$ and $m\left(\tau_{\mathrm{i}+1}\right)$ - the mass of the sample at appropriate times, $\mathrm{kg}$;

$\mathrm{W}^{\mathrm{c}}{ }_{\mathrm{K}}$ - the final humidity of the material, \%;

$t_{\text {m.a. }}{ }^{\mathrm{K}}$ - a medium-volume temperature (maximum allowed), ${ }^{\circ} \mathrm{C}$;

$\mathrm{d}$ - moisture content of the heat-coolant, $\mathrm{g} / \mathrm{kg}$ dry air;

$\delta$ - the thickness of the material layer, $\mathrm{mm}$.

material and calculating the thermal-cost of its dehydration, typically used data from the heat of vaporization, which were obtained for the conditions of evaporation of pure water from a free surface [4]. Sometimes they are clarify for drying in the area of hygroscopic moisture content of the material based on the analysis of sorption curves [5]. However, it is assumed that a significant increase in the heat of evaporation begins after the removal of all free moisture and before removal the associated moisture. However, it is known and confirmed by the results of our previous experiments that the reduction of bound water content in some plant tissues occurs during removal of free water [6]. There is an increase in the energy consumption of evaporating water from the initial stages of drying by removing a certain amount of bound water [4]. Moreover, due to the dependence of the processes of diffusion of moisture and deformation of plant tissues on the drying regime, the amount of bound water in the evaporating moisture may vary differently [7]. 
The purpose of the work. Thus, the question arose about the need to study the influence of technological parameters of the processes of pre-treatment and dehydration of vegetable raw materials on energy consumption in the manufacture of dry food powders. In particular: the process of preliminary creation of phytoestrogenic, carotene-containing plant compositions (mixtures of soybeans, carrots and spinach) and the application of the step mode of raising the temperature of the coolant during drying.

\section{Outline of the main research material.}

The main task that arises when soybeans are dried is to preserve their phytoestrogens and prevent lipid oxidation. The high content of fat in soybeans and the risk its of oxidation reduces the term of storage of raw materials. To prevent this soybean was combined with carotene-containing raw materials - carrots and spinach. Carotenoids of carrots and spinach help stabilize soybean fats and prevent them from oxidizing during the processing and storage of soy-vegetable compositions [8]. On the other hand, carotenoids are better converted to vitamin $\mathrm{A}$, which prevents the formation of cholesterol in the blood, strengthens the immune system, has antitumor and anti-stress effects, when the diet requires the required amount of protein and fat [8], which a lot in soybean. In addition, the shelf life of spinach at a temperature of $0 \ldots 1{ }^{\circ} \mathrm{C}$ and a relative humidity of $90 \ldots 95 \%$ for only 2 days, so its drying, separately and in a mixture, significantly extends the shelf life.

Based on the above, was improved the technology it was of pre-hydro-thermal treatment of phytoestrogen raw materials and mixtures based on it before drying [2-3, 9]. It consists of the following technological steps. Soaking soy in water. Washing soybeans. Soybean boiling for inactivation of anti-food components (Trypsin inhibitor) [2, 3], which increases the digestibility of soy protein. Rewashing of soybeans again. Preparation of carrots and spinach. Soaking the spinach in water with a temperature of $20 \ldots 25^{\circ} \mathrm{C}$ for 5 minutes. This operation is a must, because then there is a minimal loss of vitamins and other biologically active substances of spinach during drying. Soybeans, carrots and spinach were crushed to approximate size $7 \times 4 \times 3 \mathrm{~mm}$. Were created of soy-vegetable phytoestrogenic carotenecontaining compositions by mixing the components in $1: 1$ proportions.

In the process of drying plant materials, much energy is expended on the evaporation of moisture. The practice of drying a number of complex plant materials has shown a significant difference between the real values of heat consumption for the evaporation of moisture from them from the heat of evaporation of pure water. As the increase in energy costs in drying plant materials is associated with difficulty in permeability of water through cell membranes and the difficulty of removing water that interacts with soluble components of cellular juice and skeletal molecules, it was important to investigate the effect of the creation of functional compositions of vegetable raw materials on the specific heat of evaporation of water [10].

The calorimetric method based on continuous simultaneous measurement of the sample mass reduction and the amount of heat expended on the evaporation process in the isothermal drying process was used to determine the heat-cost on evaporation humidity from the proposed functional mixtures and their components. Experiments were performed using an improved version created installation of the DMKI-01 synchronous thermal analysis in the Institute of Engineering Thermophysics NASU. A calorimetric platform with deep cylindrical cells was used to investigate dispersed materials [11]. Conductive isothermal drying of samples weighing $0.3 \mathrm{~g}$ was occurred in the working chamber of the calorimetric unit at a temperature of $60{ }^{\circ} \mathrm{C}$ until the samples reach equilibrium moisture. A drying temperature of $60{ }^{\circ} \mathrm{C}$ was selected as the optimum for protein-containing raw materials. The mass of dry matter in the sample was determined by the method of drying inside the working chamber at $105{ }^{\circ} \mathrm{C}$.

The current values of the specific heat of evaporation of water from the sample was determined, starting from the time of establishing thermodynamic equilibrium inside the calorimetric chamber, by the formula:

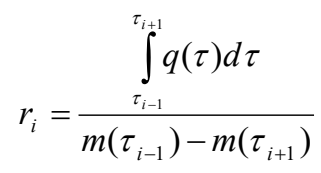

where $r_{i}$-specific heat-costs consumption for evaporation during the time from $\tau_{\mathrm{i}-1}$ to $\tau_{\mathrm{i}+1}, \mathrm{~kJ} / \mathrm{kg}$;

$\tau_{\mathrm{i}-1}$ and $\tau_{\mathrm{i}+1}$ - the value of the current time, sec;

$q(\tau)$ - the heat flow inside the working chamber as a function of time, $\mathrm{J} / \mathrm{sec}$;

$m\left(\tau_{\mathrm{i}-1}\right)$ and $m\left(\tau_{\mathrm{i}+1}\right)$ - the mass of the sample at appropriate times, $\mathrm{kg}$.

The results of measuring the value of the specific heat of evaporation of water from phytoestrogen raw materials are shown in Figure $1(a, b)$. From Figure 1 (a) we can see that at the beginning of drying the heat of evaporation of moisture from carrots and soybean-carrot composition is about $4 \ldots 5 \%$ higher than the heat of evaporation of pure water. Mixing of the components has led to the fact that 
during the drying process at a temperature of $60^{\circ} \mathrm{C}$, starting from a humidity of $65 \%$, in mixture is exothermic reaction, which is accompanied by additional heat release. As a result, the specific heat-costs for the dehydration of the soybean and carrot mixture from $50 \%$ to $30 \%$ relative humidity becomes even less than the specific heat consumption for the evaporation of pure water. It can be assumed that it was an exothermic reaction of the interaction of soybean fats with fat-soluble carotenoids, but more accurate characterization of this reaction requires further investigation. A similar pattern is observed in the study of the heat of evaporation of moisture from soy-spinach composition and its components (Figure 1 (b)).

Carotenoids - labile substances that are easily destroyed under the influence of oxygen, light and heat. Drying of the carotene-containing raw-materials at $100{ }^{\circ} \mathrm{C}$ results in the loss of about $40 \%$ of the carotenoids [8] and melaidin reactions. Drying of proteinaceous raw materials at high temperatures of the drying agent leads to denaturation of proteins. Therefore, to prevent these processes, as well as to preserve biologically active substances, it is recommended to dry protein-carotene mixtures using modes in which the temperature in the material layer will not exceed $60 \ldots 70{ }^{\circ} \mathrm{C}$. Therefore, when developing the drying technologies of the prepared compositions, a careful selection of the drying

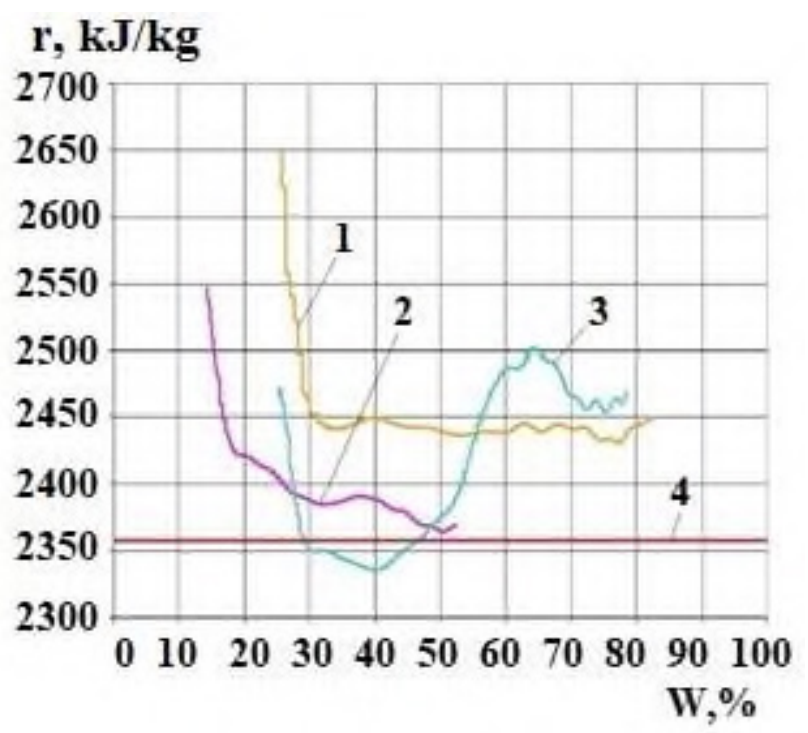

a) temperature was carried out. For this purpose, experimental studies of the drying process of the prepared raw material at different temperature conditions were carried out on a convective drying stand. Prepared mono-raw materials and compositions were placed on a mesh tray of size 100x50 mm, which was placed on the balance of the scales in the drying chamber. Thermocouples were inserted inside the material to measure material temperature changes during drying. Investigation of the drying process was carried out to the final humidity of the material $\mathrm{W}_{\mathrm{K}}^{\mathrm{c}}=4 \%$, because the drying of materials to a moisture content below $5 \%$ can significantly increase their shelf life in a powdered state [9]. To determine the current humidity of the material, the samples were dried after the experiment to a completely dry weight at $100 \ldots 105^{\circ} \mathrm{C}$. (GOST $28561-90$ «Determination of moisture content by drying to constant weight»).

For study the effect material condition (mono-rawmaterial and soybean-carrot mixture with initial humidity $\mathrm{W}=73,8 \%$ ) on the duration of drying and the quality of the dried raw material, used a temperature of $70^{\circ} \mathrm{C}$ coolant, because, based on our previous studies [9], increasing the temperature of the coolant to $80{ }^{\circ} \mathrm{C}$ leads to oxidation of lipids and partial destruction of carotenoids. Drying conditions of soybeans, carrots and mixtures thereof were the same. A general analysis of the drying and temperature

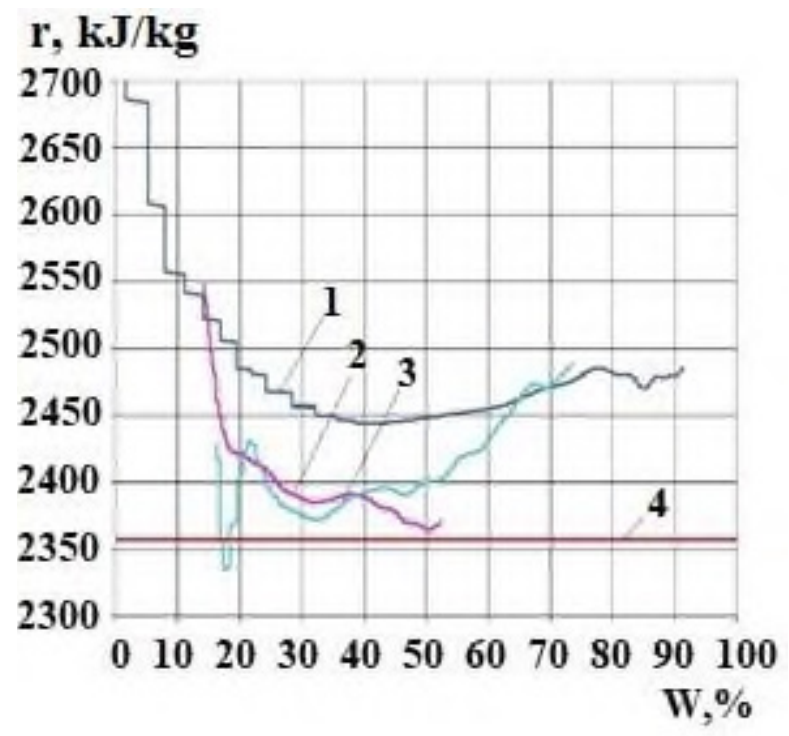

b)

Fig.1. Dependence of the specific heat of evaporation of water from samples from there relative moisture during drying: a) 1 -carrot, 2 -soy, 3 -soy-carrot mixture, 4 -water;

б) 1 - spinach, 2 - soy, 3 - soy-spinach mixture, 4 - water. 
curves (Figure 2) showed that the temperature on the material during the drying process rises: initially intensively, that is, on diapason up to the temperature of the middle of the bulk of the material layer $t_{m . a}=60{ }^{\circ} \mathrm{C}$ soybean moisture content can drop to $20 \%$, carrot - to $54 \%$, soybean-carrot mixture to $26,8 \%$, and then slowly, approaching the heat-coolant temperature (within to the temperature of the middle of the bulk of the material layer $t_{m \cdot a}=61-70{ }^{\circ} \mathrm{C}$ ). It is known that after the material reaches a temperature range of $70-80{ }^{\circ} \mathrm{C}$, its sharp darkening and deterioration of appearance occurs [8]. In the study at temperature up to $70{ }^{\circ} \mathrm{C}$ visual changes in the color gamut and appearance did not occur. Also, drying the soybean-carrots mixture showed at $5.6 \%$ reduction in the drying time relative to the mono-raw material (carrots)
(Figure 2, curves 2 and 1). It is known that saving the operating time of technological equipment in production conditions is equivalent to reducing energy consumption [12].

Convective drying processes are one of the largest energy intensive industrial processes. One way to solve this problem is to develop energy-efficient drying modes. In order to reduce the energy consumption of the drying process, soybean-carrot mixture drying studies were carried out using a stepwise change in the coolant temperature of $100 / 70{ }^{\circ} \mathrm{C}$. As the temperature in the medium-volume layer of material approached the allowable $\left(70{ }^{\circ} \mathrm{C}\right)$, the heatcoolant temperature was lowered from $100{ }^{\circ} \mathrm{C}$ to $70{ }^{\circ} \mathrm{C}$ to prevent material from overheating (Figure 3 ). The use of

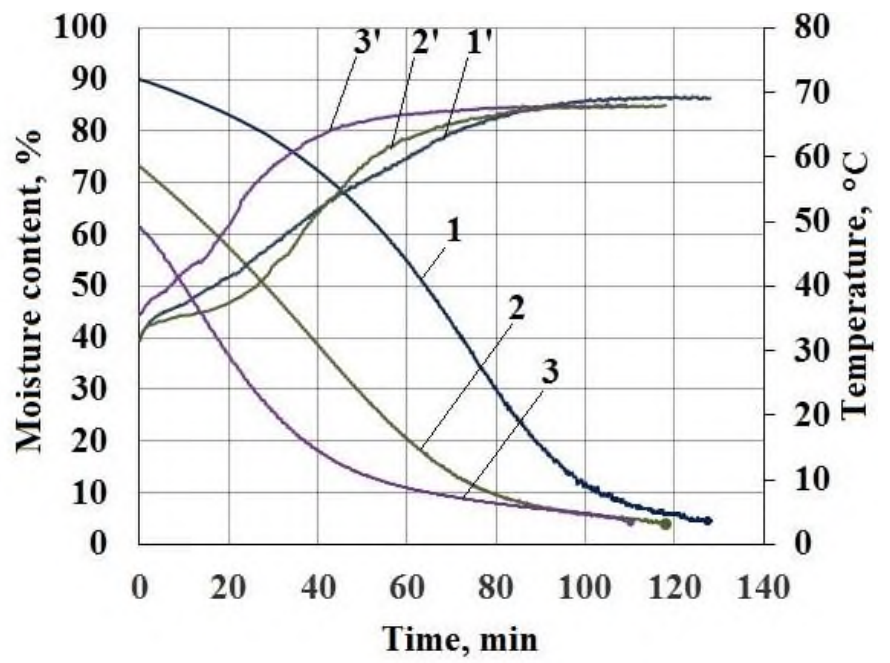

Fig.2. Kinetics of drying $(1,2,3)$ and temperature curves $(1,2,3$ ') mono-raw-material and soybeancarrot mixture under regime parameters $t=70^{\circ} \mathrm{C}, \mathrm{v}=2,5 \mathrm{~m} / \mathrm{sec} ; \mathrm{d}=10 \mathrm{~g} / \mathrm{kg} \mathrm{dry}$ air, $\delta=15 \mathrm{~mm}$ : 1, 1'-carrot; 2, 2'- soybean-carrot (1:1); 3, 3'- soybean

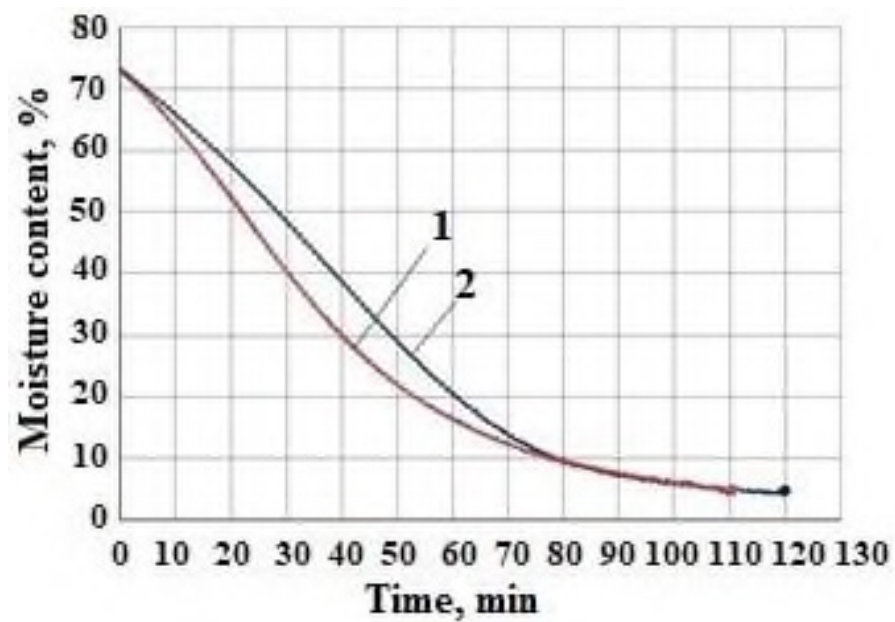

a)

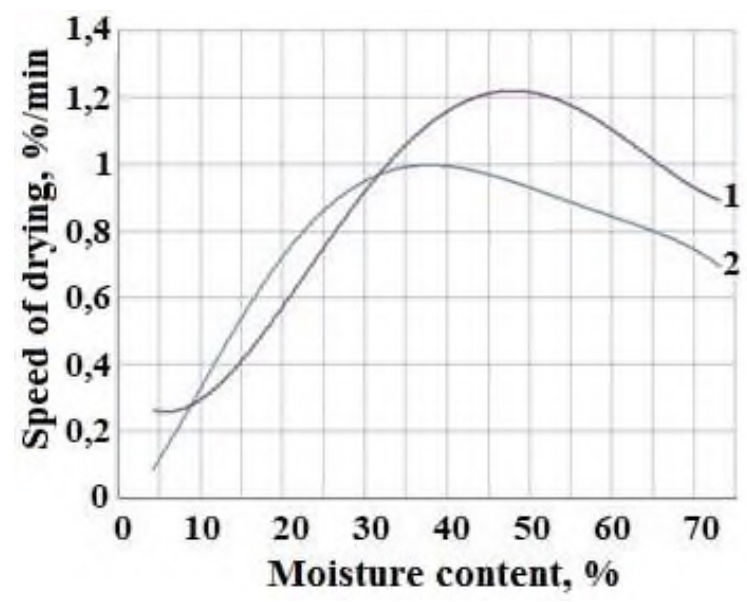

b)

Fig. 3. Change in moisture content (a) and drying speed (b) soy-carrot mixture under the influence of heat-coolant temperature $70^{\circ} \mathrm{C}$ and $100 / 70^{\circ} \mathrm{C}$. 
high temperatures is possible only at the stage of removal of free moisture, prolonged use of high-temperature mode of drying $\left(100^{\circ} \mathrm{C}\right)$ leads to the undesirable melanoidin reaction of proteins with amino acids, as a result of which they are destroyed, the qualitative characteristics of the raw material are changed [2]. The process of removing moisture from the soybean-carrot mixture when using a two-stage mode (Figure 3 (b), curve 1) is characterized by a higher velocity, its maximum speed higher by $0.2 \% / \mathrm{min}$ than at one-stage mode (Figure 3 (b), curve 2). After reaching a mediumvolume temperature $t_{m, a}=66 \ldots 70^{\circ} \mathrm{C}\left(\mathrm{W}^{\mathrm{c}}=32 \%\right)$ the rate of drying of the composition for the two-stage temperature regime (Figure 3 (b), curve 1) is lower than the one-stage mode (Figure 3 (b), curve 2), but the time to reach the final moisture content differs significantly. The two-stage temperature regime reduced the drying time by $8 \%$ relative to the one-stage.

Mode options: $\delta=15 \mathrm{~mm}, \mathrm{~W}^{\mathrm{c}}=4 \%$; $=2,5 \mathrm{~m} / \mathrm{sec}$, $\mathrm{d}=10 \mathrm{~g} / \mathrm{kg}$ dry air. $1-100 / 70{ }^{\circ} \mathrm{C}, 2{ }^{\mathrm{K}}-70{ }^{\circ} \mathrm{C}$.

Soy proteins are by their nature heat-sensitive and after breaking the temperature threshold of $65 \ldots 75^{\circ} \mathrm{C}$ (and in some sources $60^{\circ} \mathrm{C}$ ) their destruction begins [13]. Since it is difficult to track the onset of an overheating process in the middle-volume of the material under industrial conditions, then the study of the process of single-stage drying of soybean, spinach and soybean-spinach mixture with initial moisture $\mathrm{W}^{\text {rel. }}=73,5 \%$ was carried out at a heat-coolant temperature $60{ }^{\circ} \mathrm{C}$. As in the study of the soybean-carrot mixture, a significant intensification of the drying process was observed (Figure 4). As a result of the combination of phytoestrogenic raw materials ( carotene-containing raw materials ( spinach, $\mathrm{W}_{\text {initial }}=93 \%$ ) there is an intensification of the drying process compared to spinach by $10 \%$ and soybean by $41 \%$, which also has the effect of reducing the energy consumption of the drying process [14]. Comparing curve 2 in figure 4 and curve 2 in figure 2, it is impossible not to notice that in the case of drying soy-spinach mixture at $60{ }^{\circ} \mathrm{C}$ coolant, the drying time is shorter than when drying soy-carrot mixture at $70^{\circ} \mathrm{C}$ coolant. The specific heat costs for removing moisture from soybean spinach mixture are also $10 \%$ less than for soybeancarrots (Figure 1 (a), curve 3 and figure 1 (b), curve 3).

In the study of the influence of the step change of the heat-coolant temperature on the drying process of soybeanspinach mixture (Figure 5), the heat-coolant temperature was reduced from the initial 100 to $60{ }^{\circ} \mathrm{C}$, when the temperature in the material layer approached to the allowable $\left(60^{\circ} \mathrm{C}\right)$ [14]. From Figure 5 (a) we can see that the stepwise $\left(100 / 60{ }^{\circ} \mathrm{C}\right)$ change in the coolant temperature during drying of soybean-spinach mixture (curve 1) allows to reduce the drying time compared to the mono-temperature regime (curve 2), the process is intensified by $21 \%$. This intensification outweighs the effect of using a stepped temperature regime $\left(100 / 70{ }^{\circ} \mathrm{C}\right)$ when drying the soybean-carrot mixture (Figure 3 (a), curves 1 and 2). As can be seen from Figure 5 (b), the use of a stepwise change of temperature

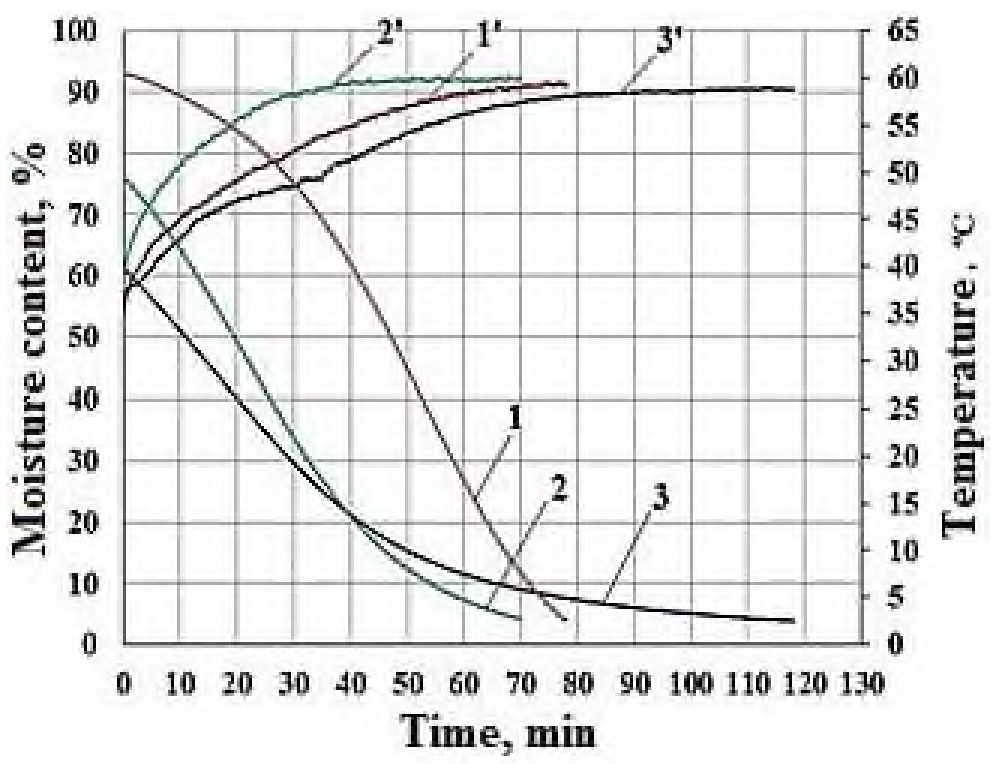

Figure 4. Change of moisture content (1,2,3) and temperature curves (1',2',3') mono-raw-material and soy-spinach mixture over time. Regime parameters: $t=60^{\circ} \mathrm{C}, v=2,5 \mathrm{~m} / \mathrm{sec} ; \mathrm{d}=10 \mathrm{~g} / \mathrm{kg} \mathrm{dry} \mathrm{air}$, $\delta=15 \mathrm{~mm} .1$, 1'-spinach, 2, 2'- soy-spinach mixture,3, 3'- soybean. 


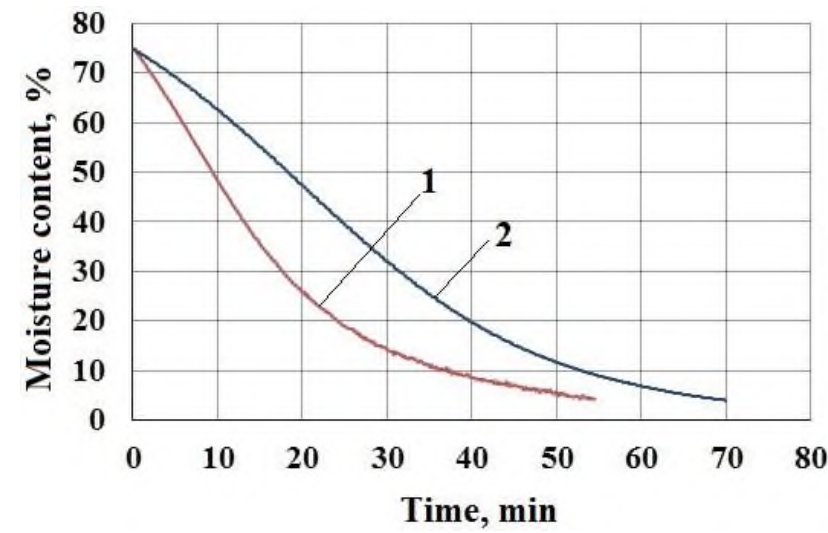

a)

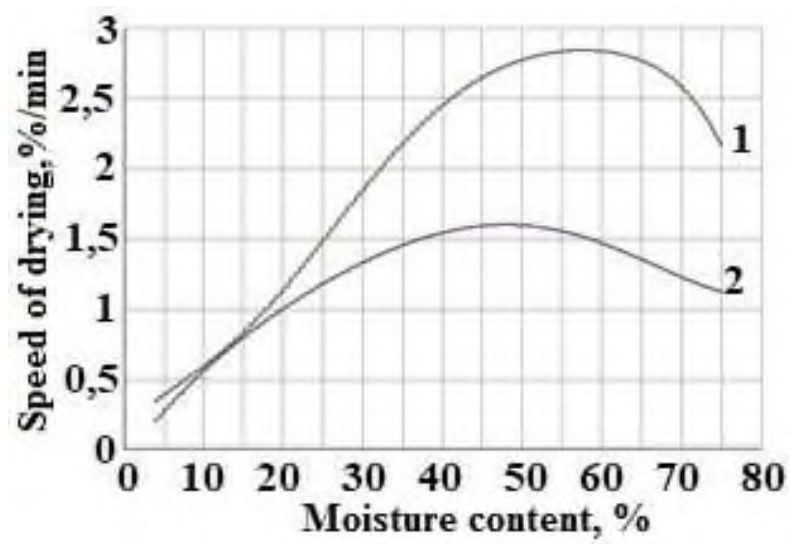

b)

Fig. 5. Change in moisture content (a) and drying speed (b) soy-spinach mixture under the influence of heat-coolant temperature $60^{\circ} \mathrm{C}$ and $100 / 60^{\circ} \mathrm{C}$. Regime parameters: $\delta=15 \mathrm{~mm}, \mathrm{Wc \kappa}=4 \% ; v=2,5 \mathrm{M} / \mathrm{c}$, $d=10 \mathrm{~g} / \mathrm{kg}$ dry air. $1-100 / 60^{\circ} \mathrm{C}, 2-60^{\circ} \mathrm{C}$.

$\left(100 / 60{ }^{\circ} \mathrm{C}\right)$ allowed to increase the average speed of the process, maximum drying speed $N_{\max }=2,8 \%$ /min (Figure 5 (b), curve 1), which is 1.75 times higher than the one-step mode $60^{\circ} \mathrm{C}$ (Figure $5(\mathrm{~b})$, curve 2) [12].

Conclusions. The results of studies have shown that the creation of a composition of soybeans, carrots and spinach at the stage of preliminary preparation of phytoestrogenic carotene-containing vegetable raw materials for drying can significantly intensify the drying process of raw materials and reduce its energy consumption.

It is established that the specific heat consumption for the evaporation of water from the developed soybean based plant compositions with the addition of carrots and spinach is less than the cost of evaporation of water from the individual components. When the moisture content of the material is from 50 to $30 \%$, the specific heat consumption of evaporation is lower than the specific heat consumption for evaporation of pure water. This can be explained by the fact that in drying of the proposed composition registers an integral thermal effect between the components of the mixture, accompanied by an exothermic effect, and due to the interaction of the components in the composition is intensified drying process.

It was found that previous layout in composition of soybeans with carrots accelerates the process of drying relative to carrots by $5.6 \%$ when using a single-stage $\left(70{ }^{\circ} \mathrm{C}\right)$ temperature regime and by $8 \%$ when using a twostage $\left(100 / 70{ }^{\circ} \mathrm{C}\right)$ temperature regime. Previous layout of soybeans with spinach speeds up the process of single-stage $\left(60{ }^{\circ} \mathrm{C}\right)$ drying compared to spinach by $10 \%$ and soybean by $41 \%$, and two-stage $\left(100 / 60{ }^{\circ} \mathrm{C}\right)$ drying - by $21 \%$.
The difference in the time required for drying the soybeancarrot and soybean spinach compositions is due to the different structure and biochemical composition of the mono-raw material.

\section{REFERENCES}

1. Bichkov Ya.M. Dmitryuk T.I. [Methods of obtaining dry powders from vegetable raw materials] // Naukovi pratsi [Scientific works], Issue 46, Vol.1. PP. 204-208 (Ukr)

2. Petrova Zh.O., Slobodianiuk K.S. [Intensification of the process of drying the vegetable mixture of soybean and batat] // Naukovi pratsi Odeskoi natsionalnoi akademii kharchovykh tekhnolohii [Scientific works Odessa National Academy of Food Technologies] [. 2018. Vol. 82 (Issue 1). PP.18-22. (Ukr)

3. Petrova Zh.O., Slobodianiuk K.S. [Energy effective drying modes of soy-vegetable compositions] // Ukrainian Journal of Food Science. 2017. Vol. 5, Issue 1. PP. 150-160. (Eng)

4. Dmytrenko N.V. Vplyv tekhnolohichnykh parametriv protsesu sushinnia na teplotu vyparovuvannia volohy $\mathrm{z}$ roslynnykh tkanyn [ The influence of technological parameters of the drying process on the heat of evaporation of moisture from plant tissues] // Naukovi pratsi Odeskoi natsionalnoi akademii kharchovykh tekhnolohii [Scientific works Odessa National Academy of Food Technologies]. 2015. Issue 47( Vol 2). PP. 52-55. (Ukr)

5. Potapov V.A. Strukturno-enerhetychnyi metod analizu izoterm sorbtsii-desorbtsii kharchovoi syrovyny [Structuralenergy method of analysis of sorption-desorption isotherms of food raw materials]// Prohresyvni tekhnika ta tekhnolohii 
kharchovykh vyrobnytstv, restorannoho hospodarstva ta torhivli : Zbirnyk naukovykh prats [ Progressive Techniques and Technologies for Food, Restaurant and Trade: A Collection of Scientific Papers]. Kharkiv: KhDUKhT, 2005. Issue 1. PP.313-322. (Ukr)

6. Sniezhkin Yu.F., Mykhailyk V.A., Dmytrenko N.V. Dynamika zminy stanu vody v parenkhimnykh tkanynakh roslyn pry sushinni [Dynamics of change of water status in parenchymal tissues of plants during drying] // Promyshlennaya teplotekhnika [Industrial Heat Engineering]. 2011. Issue 33, Vol. 2. PP. 35-40. (Ukr)

7. Nykytenko N. Y., Snezhkyn Yu. F., Sorokovaia N. N. Dynamyka protsessov teplomassoperenosa, fazovykh prevrashchenyi y usadky pry obezvozhyvanyy kolloydnykh kapylliarno-porystykh materyalov [Dynamics of heat and mass transfer processes, phase transformations and shrinkage during dehydration of colloidal capillary-porous materials] // Promyshlennaya teplotekhnika [Industrial Heat Engineering]. 2003. Issue 25, Vol. 3. PP. 56-66. (Rus)

8. Sniezhkin Yu.F., Petrova Zh.O., Paziuk V.M. Enerhoefektyvni teplotekhnolohii vyrobnytstva funktsionalnykh kharchovykh poroshkiv [Energy efficient heat technologies for the production of functional food powders]. Vinnytsia: VNAU, 2016. (Ukr)

9. Petrova Zh.O. Stvorennia enerhoefektyvnykh teplotekhnolohii vyrobnytstva funktsionalnykh kharchovykh poroshkiv sushky : dys. ... dokt. tekhn. nauk [Creation of energy efficient heat technologies of production of functional food powders of drying: dis. ... doc. tech. of sciences] : 05.14.06. Kyiv, ITTF NANU, 2013. (Ukr)

10. Petrova Zh.O., Dmytrenko N.V., Slobodianiuk K.S. Vyznachennia teploty vyparovuvannia soievo-shpynatnoi sumishi [Determination of evaporation heat of soybean spinach mixture] / Mizhnarodna naukova internetkonferentsiia «Informatsiine suspilstvo: tekhnolohichni, ekonomichni ta tekhnichni aspekty stanovlennia» [International scientific internet conference "Information society: technological, economic and technical aspects of becoming"]. Issue 29, Ternopil 2018. PP. 101-103. (Ukr.)
11. Patent of Ukraine No 84075 MPK G01 N25/26, G01 N25/28. Kalorymetrychnyi prystrii dlia vyznachennia pytomoi teploty vyparovuvannia volohy i orhanichnykh ridyn $\mathrm{z}$ materialiv [Calorimetric device for determining the specific heat of evaporation of moisture and organic liquids from materials] / Sniezhkin Yu.F., Dekusha L.V., Dubovikova N.S., Hryshchenko T.H., Vorobiov L.I., Boriak L.A. Application № a200613266 15.12.06; issued 10.09.08; publ. 10.09.08; Biul. No17. 10 P. (Ukr)

12. Slobodianiuk K.S. Intensyfikatsiia protsesu sushinnia fitoestrohennoi syrovyny na osnovi soi: avtoref. dys. ... kand. tekhn. nauk [Intensification of the process of drying phytoestrogenic raw materials on the basis of soy: abstract. diss. ... Cand. tech. of sciences]: 05.14.06. Kyiv, ITTF NANU, 2020. 30 P. (Ukr)

13. Berezov T. T., Korovkyn B. F. Byolohycheskaia khymyia: Uchebnyk. 3-e yzd., pererabotannoe y dopolnenoe [Biological Chemistry: Textbook. - 3rd ed., Revised and supplemented]. M.: Medytsyna, 1998. 704 P. (Rus)

14. Petrova Zh.O., Slobodianiuk K.S. Intensyfikatsiia protsesu sushinnia soievo-shpynatnoi kompozytsii [Intensification of the drying process of soybean-spinach mixture] / Materialy Kh Mizhnarodnoi naukovo-prakt. konf. «Problemy teplofizyky ta teploenerhetyky» [Proceedings of the X International Scientific Practice. Conf. «Problems of Thermophysics and Heat Power Engineering»], Kyiv, ITTF NANU, 23-26 may 2017. (Ukr) 


\section{ВПЛИВ ТЕХНОЛОГІЧНИХ РЕЖИМНИХ ПАРАМЕТРІВ ТА ПОПЕРЕДНЬОЇ ПІДГОТОВКИ НА КІНЕТИКУ ЗНЕВОДНЕННЯ ТА ЕНЕРГОВИТРАТИ В ПРОЦЕСІ СУШІННЯ ФІТОЕСТРОГЕННИХ КОМПОЗИЩЙ}

Петрова Ж.О., докт. техн. наук, Слободянюк К.С., Дмитренко Н.В., канд. техн. наук

Інститут технічної теплофізики НАН України, вул. Марії Капніст, 2а, Київ, 03057, Україна

\section{https:doi.org/10.31472/ttpe.2.2020.4}

У зв'язку з високими енергетичними витратами на сушильні процеси виникає необхідність пошуку шляхів зниження енергоспоживання. Однак, сушіння рослинних матеріалів - це теплотехнічний процес під час якого змінюються технологічні та біохімічні властивості матеріалу. Застосування невідповідних режимних параметрів процесу щодо властивостей конкретного рослинного матеріалу може значно погіршити якісні характеристики кінцевого продукту. Щоб уникнути цього було вдосконалено попередню гідротермічну обробку фістоестрогенної рослинної сировини та іiі сумішей 3 каротиновмісними овочами; розроблено ступеневі режими зміни температури в процесі сушіння. Все це в комплексі дозволило знизити загальну тривалість сушильного процесу і скоротити час впливу високих температур на термолабільний матеріал.

У статті викладені результати дослідження впливу попередньої підготовки фітоестрогенної сировини і ступеневої зміни температури в процесі сушіння на енерговитрати при виробництві сухих порошків. А також результати досліджень по визначенню витрат теплоти на випаровування вологи 3 фітоестрогенних рослинних сумішей: соя-морква і соя-шпинат. Експериментально доведено, що питомі витрати теплоти на зневоднення композиції із сої та моркви від 50\% до $30 \%$ вологості менше ніж питомі витрати теплоти на випаровування чистої води. Попередне змішування сої 3 морквою прискорює процес сушіння на 5,6\% щодо сушіння моркви, а сої зі шпинатом - на 10\% (відносно часу сушіння шпинату) й $41 \%$ (відносно часу сушіння гідротермічно обробленої подрібненої сої). Використання ступеневих режимів зміни температури теплоносія додатково інтенсифікує процес сушіння композиції сояморква на $8 \%\left(100 / 70{ }^{\circ} \mathrm{C}\right)$, а композиції соя-шпинат на $21 \%\left(100 / 60{ }^{\circ} \mathrm{C}\right)$.

Отримані результати дозволяють зробити процес менш енерговитратним i максимально зберегти біологічно активні речовини термолабільного фітоестрогенного рослинного матеріалу.
Бібліографія 14, рис. 5.

Ключові слова: фітоестрогени, вологовміст, випаровування, сушіння, енерговитрати.

1. Бичков Я.М. Дмитрюк T.I. Способи отримання сухих порошків з рослинної сировини // Наукові праці, випуск 46, том 1. - с. 204-208

2. Петрова Ж.О., Слободянюк К.С. Інтенсифікація процесу сушіння рослинної суміші з сої та батату // Наукові праці [Одеської національної академії харчових технологій]. - 2018. - Том 82 (Випуск 1). - С.18-22.

3. Petrova Zh.O., Slobodianiuk K.S. Energy effective drying modes of soy-vegetable compositions // Ukrainian Journal of Food Science. 2017. Volume 5, Issue 1, p. $150-160$.

4. Дмитренко Н. В. Вплив технологічних пара-метрів процесу сушіння на теплоту випаровування вологи з рослинних тканин // Наукові праці [Одеської національної академії харчових технологій]. - 2015. - Вип. 47(2). C. 52-55.

5. Потапов B.A. Структурно-енергетичний метод аналізу ізотерм сорбції-десорбції харчової сировини // Прогресивні техніка та технології харчових виробництв, ресторанного господарства та торгівлі : Зб. наук. праць. - Харків: ХДУХТ, 2005. - вип.1. - С.313-322.

6. Снєжкін Ю.Ф., Михайлик В.А., Дмитренко Н.В. Динаміка зміни стану води в паренхімних тканинах рослин при сушінні // Промышленная теплотехника. - 2011. T.33, №2. - C. 35-40.

7. Никитенко Н. И., Снежкин Ю. Ф., Сороковая Н. Н. [Динамика процессов тепломассопереноса, фазовых превращений и усадки при обезвоживании коллоидных капиллярно-пористых материалов] // Промышленная теплотехника. - 2003. - Т. 25, № 3. - С. 56-66.

8. Снєжкін Ю.Ф., Петрова Ж.О., Пазюк В.М. Енергоефективні теплотехнології виробництва функціональних харчових порошків. Вінниця: ВНАУ, 2016.

9. Петрова Ж.О. Створення енергоефективних теплотехнологій виробництва функціональних харчових порошків : дис. ... докт. техн. наук : 05.14.06. - Київ, ITTФ НАНУ, 2013.

10. Петрова Ж.О., Дмитренко Н.В., Слободянюк К.С. Визначення теплоти випаровування соєво-шпинатної суміші / Міжнародна наукова інтернет-конференція «Інформаційне суспільство: технологічні, економічні та технічні аспекти становлення». - Випуск 29, Тернопіль 2018. - C. 101-103.

11. Патент Украӥни № 84075 МПК G01 N25/26, G01 N25/28. Калориметричний пристрій для визначення питомої теплоти випаровування вологи і органічних рідин 3 матеріалів / Снєжкін Ю.Ф., Декуша Л.В., 
Дубовікова Н.С., Грищенко Т.Г., Воробйов Л.Й., Боряк Л.А. - Заявка № а200613266; заявл. 15.12.06; видано 10.09.08; опубл. 10.09.08; Бюл. No17. - 10 с.

12. Слободянюк К.С. Інтенсифікація процесу сушіння фітоестрогенної сировини на основі сої: автореф. дис. ... канд. техн. наук : 05.14.06 - Київ, ІТТФ НАН України, 2020. - $30 \mathrm{c}$.

13. Березов Т. Т., Коровкин Б. Ф. Биологическая химия: Учебник.- 3-е изд., перераб. и доп.- М.: Медицина, 1998.- $704 \mathrm{c}$.
14. Петрова Ж.О., Слободянюк К.С. Інтенсифікація процесу сушіння соєво-шпинатної композиції / Матеріали X Міжнародної науково-практ. конф. «Проблеми теплофізики та теплоенергетики», Київ: ІТТФ НАНУ, 23-26 травня 2017.
Отримано 17.04.2020

Received 17.04.2020 